\title{
ASPEK BIOLOGI UDANG JERBUNG (Penaeus merguiensis de Man, 1888) DI PERAIRAN KENDAL, JAWA TENGAH
}

\author{
Biological Aspects of Banana Shrimp (Penaeus merguiensis de Man, 1888) \\ in the Kendal Waters, Central Java
}

\section{Katrina Dwika Sari, Suradi Wijaya Saputra*) dan Anhar Solichin}

Program Studi Manajemen Sumberdaya Perairan, Departemen Sumberdaya Akuatik

Fakultas Perikanan dan Ilmu Kelautan, Universitas Diponegoro

J1. Prof. Sudato, SH, Tembalang, Semarang, Jawa Tengah - 50275, Telp/Fax. +6224 7474698

Email: katrinadwikasari@gmail.com

\begin{abstract}
ABSTRAK
Penangkapan udang $P$. merguiensis yang dilakukan secara terus menerus dan tidak sesuai kaidah yang baik dapat mengancam keberlangsungan hidup udang. Tujuan dari penelitian ini yaitu untuk mengkaji aspek-aspek biologi udang P. merguiensis seperti komposisi hasil tangkapan, struktur ukuran, nisbah kelamin, tingkat kematangan gonad (TKG), sifat pertumbuhan, faktor kondisi, dan ukuran pertama kali udang tertangkap $\left(\mathrm{Lc}_{50 \%}\right)$. Selain itu, membuat konsep pengelolaan sumberdaya perikanan udang $P$. merguiensis. Metode penelitian yang digunakan yaitu metode survei. Pengambilan sampel udang P. merguiensis dilakukan di TPI Bandengan dan TPI Tawang Kabupaten Kendal, pada bulan Mei sampai Agustus 2016. Setiap bulan dilakukan satu kali pengambilan sampel. Sampel udang diambil dari total hasil tangkapan salah satu perahu pada setiap TPI. Hasil penelitian menunjukkan modus panjang karapas $20 \mathrm{~mm}$ pada bulan Juni dan Juli 2016, sedangkan pada bulan Mei dan Agustus 2016 modus panjang karapas $22 \mathrm{~mm}$ dan $24 \mathrm{~mm}$. Perbandingan nisbah kelamin P. merguiensis jantan betina 1:0,95. Udang P. merguiensis jantan dan betina memiliki sifat pertumbuhan allometrik positif karena nilai b jantan dan betina sebesar 3,29 dan 3,23. Faktor kondisi udang $P$. merguiensis jantan dan betina sebesar 1,094 dan 1,096. Tingkat kematangan gonad udang P. merguiensis belum ada yang matang. Ukuran $\mathrm{Lc}_{50}$ udang $P$. merguiensis jantan dan betina pada ukuran karapas $28 \mathrm{~mm}$ dan $27 \mathrm{~mm}$. Konsep pengelolaan udang $P$. merguiensis di perairan Kendal yaitu mengganti alat tangkap arad menjadi trammel net, dan pengaturan daerah pengoperasian jauh dari pantai agar ukuran udang yang tertangkap adalah udang berukuran layak tangkap.
\end{abstract}

Kata kunci : Penaeus merguiensis, Aspek Biologi, Perairan Kendal

\section{ABSTRACT}

Continuous fishing can threat the sustainability and not according to the rules of $P$. merguiensis shrimp resources. The objectives of this research were to know biological aspect such as composition of the catch, size of structure, sex ratio, gonad maturities (TKG), growth, condition factor, and first of length capture (Lc50\%). In addition, was made management fisheries $P$. merguiensis shrimp resource. The method used in this research was survei method. Sampling was conducted in shrimp P. merguiensis Bandengan TPI and TPI Tawang Kendal, from Mei to Agustus 2016. Each month one-time sampling. Shrimp samples were taken is about of the total fishing catch one of the boats at each TPI. The results showed that the mode carapace length of $20 \mathrm{~mm}$ in Juni and Juli 2016, while in Mei and Agustus 2016 the mode carapace length of $22 \mathrm{~mm}$ and $24 \mathrm{~mm}$. Sex ratio of P. merguiensis shrimp male and female was 1:0,95. Growth of $P$. merguiensis male and female was positive allometric, because $b$ value male and female was 3,29 and 3,23. Condition factor of P. merguiensis male and female was 1,094 and 1,096. Gonad maturities of P. merguiensis shrimp yet mature. Size Lc $c_{50 \%}$ P. merguiensis shrimp male and female carapas length $28 \mathrm{~mm}$ and $27 \mathrm{~mm}$.the concept of management of shrimp P.merguiensis in Kendal water replace the capture tool arad became a trammel net mesh size, and setting the operating areas away from the coast so that the size of the shrimp that are caught are decent-sized shrimp size.

Keywords: Penaeus merguiensis, Biological Aspect, Kendal Water

*) Penulis penanggungjawab

\section{PENDAHULUAN}

Kabupaten Kendal merupakan salah satu daerah memiliki potensi tinggi dibidang perikanan tangkap. Komoditas unggulan dari perairan pantai Kendal antara lain udang. Salah satu jenis udang yang banyak tertangkap di perairan Utara Kendal adalah udang Jerbung ( $P$. merguiensis). Udang Jerbung merupakan salah satu jenis udang yang memiliki nilai ekonomis tinggi. Menurut (Garcia dan Le Reste (1981) dalam Subagyo (2005), udang penaeid merupakan salah 
satu sumber daya alam dunia yang sangat menguntungkan karena nilai atau harganya tinggi dan permintaan pasar yang kuat. Salah satu spesies dari penaeid adalah P. merguiensis.

Tingginya intensitas penangkapan udang $P$. merguiensis di perairan Utara Kendal memungkinkan perkembangan stok terhambat. Selain itu, juga dapat mengakibatkan terancamnya kelestarian populasi udang $P$. merguiensis.

Penelitian ini bertujuan untuk mengkaji aspek biologi udang $P$. merguiensis meliputi struktur ukuran, hubungan panjang dan berat, tingkat kematangan gonad (TKG), nisbah kelamin, faktor kondisi, ukuran pertama tertangkap, ukuran pertama matang gonad, dan sifat pertumbuhan. Aspek biologi sangat diperlukan dalam pengelolaan sumberdaya udang tersebut. Berdasarkan hasil kajian tersebut diharapkan dapat disusun rumusan atau konsep pengelolaan stok udang $P$. merguiensis di perairan sebelah Utara Kendal.

\section{MATERI DAN METODE PENELITIAN}

\section{Metode Penelitian \\ Pengambilan sampel}

Pengambilan sampel udang P. merguiensis dilakukan pada TPI Tawang dan TPI BandenganBerdasarkan hasil survei banyak didaratkan perahu-perahu penangkapan udang $P$. merguiensis. Sampel udang diambil dari total hasil tangkapan salah satu perahu pada setiap TPI. Pemilihan sampel kapal dilakukan dengan mengikuti prosedur yang dikemukakan oleh Sadhotomo dan Potier (1991) dalam Saputra et al. (2009), sebagai berikut:

a) Jika kapal yang mendarat kurang dari 5 buah, dipilih satu kapal yaitu kapal nomor satu; dan

b) Jika kapal yang datang lebih dari 5 buah, maka dipilih 2 buah kapal sebagai kapal sampel. Kapal sampel pertama adalah kapal nomor urut 1 dari daftar nomor urut kapal. Kapal sampel kedua adalah kapal nomor 2 yang daerah penangkapannya berbeda dengan kapal nomor 1 . Jika daerah penangkapannya sama dengan kapal nomor 1 , maka kapal sampel kedua adalah kapal nomor berikutnya dengan daerah penangkapan yang berbeda dengan kapal nomor 1, dan seterusnya jumlah kapan samepl mengikuti kelipatan 5.

Jumlah sampel diambil berdasarkan kriteria sebagai berikut: jika jumlah populasi sampel yang didaratkan di TPI diatas 1000 ekor maka jumlah sampel yang diambil secara acak sebesar $10 \%$ dari populasi yang didaratkan, apabila jumlah sampel yang didaratkan diatas 100 ekor dan kurang dari 1000 ekor maka jumlah sampel yang diambil secara acak sebesar 30\% dari jumlah populasi yang didaratkan, dan apabila sampel yang didaratkan kurang dari 100 ekor maka jumlah sampel yang diambil harus 100\% (Mustafa, 2000). Pengambilan sampel dilakukan setiap satu bulan sekali selama 4 bulan, mulai dari bulan Mei hingga Agustus 2016.

\section{Analisis Data}

\section{Struktur Ukuran}

Analisis status pemanfaatan udang Penaeus merguiensis dapat dilihat berdasarkan struktur ukuran salah satunya yaitu sebaran frekuensi panjang (Fi). Sebaran frekuensi panjang ditampilkan dalam bentuk histogram, dan dibandingkan antar waktu untuk setiap spesies udang $P$. merguiensis yang di temukan. Dengan demikian akan terlihat udang yang tertangkap terdiri dari satu kelompok ukuran atau lebih

\section{Hubungan Panjang Berat}

Analisis hubungan panjang dengan Bobot menggunakan persamaan sebagai berikut (Effendi, 2002)

$$
\mathrm{W}=\mathrm{aL}^{\mathrm{b}}
$$

Keterangan:

$\mathrm{W}=$ berat tubuh $($ gram $)$

$\mathrm{L}=$ panjang karapas $(\mathrm{mm})$

$\mathrm{a}=$ Intercept

$\mathrm{b}=$ Slope

Untuk mempermudah dalam perhitungan persamaan tersebut dapat digambarkan dalam bentuk linier yaitu:

$$
\log \mathrm{W}=\log \mathrm{a}+\mathrm{b} \log \mathrm{L}
$$

$\mathrm{a}$ dan $\mathrm{b}$ adalah konstanta yang diperoleh dari analisis regresi linier.

Untuk menguji nilai b dapat dilakukan dengan melakukan uji t dengan persamaan sebagai berikut:

keterangan:

$$
t=\frac{3-b}{\$ b}
$$

$\mathrm{Sb}=$ Simpangan baku $\mathrm{b}$

$\mathrm{B}=$ Slope

\section{Faktor Kondisi}

Apabila nilai $b=3$ (pola pertumbuhan isometrik) untuk perhitungan faktor kondisi digunakan rumus (Effendi, 2002)

$$
\mathrm{K}=\frac{10^{3} \times \mathrm{W}}{\mathrm{L}^{3}}
$$

Apabila hasil perhitungan yang didapat adalah angka $b \neq 3$ (pola pertumbuhan alometrik) maka faktor kondisi dihitung dengan rumus: 
Keterangan:

$$
\mathrm{K}=\frac{\mathrm{W}}{\mathrm{aL}^{\mathrm{b}}}
$$

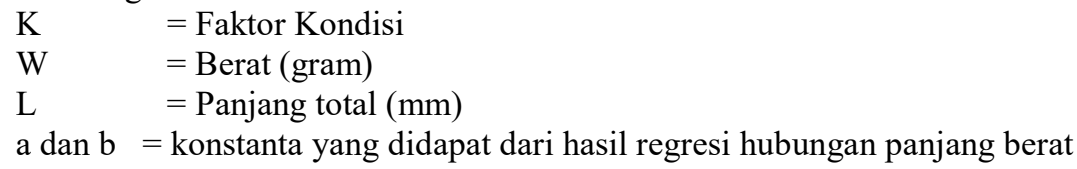

\section{Ukuran Pertama Tertangkap (Lc50\%)}

Ukuran panjang karapas pertama tertangkap $\mathrm{Lc}_{50 \%}$ diperoleh melalui ploting antara persentase frekuensi kumulatif ukuran udang dengan panjang udang menggunakan metode kurva logistik baku. Pada titik potong antara kurva dengan titik 50\% yang ditarik memotong sumbu x (panjang), maka diperoleh ukuran tengah udang yang tertangkap. Nilai tersebut akan menjelaskan bahwa 50\% udang yang tertangkap kurang dari ukuran udang tersebut dan 50\% lainnya berukuran lebih besar dari ukuran udang tersebut (Saputra, 2009).

\section{Nisbah Kelamin}

Persamaan yang digunakan untuk menghitung nisbah kelamin adalah sebagai berikut (Saputra et al. 2009)

Keterangan: $\quad$ NK: Nisbah Kelamin

$$
\mathrm{NK}=\frac{\mathrm{N}_{\mathrm{bi}}}{\mathrm{N}_{\mathrm{ji}}}
$$

$\mathrm{N}_{\mathrm{bi}}$ : Jumlah udang betina

$\mathrm{N}_{\mathrm{ji}}$ : Jumlah udang jantan

Nisbah kelamin dihitung dengan cara membandingkan jumlah udang jantan dengan jumlah udang betina, dengan menggunakan uji Chi-Square (Hadi dalam Suparjo, 2005), yaitu:

$$
\mathrm{X}^{2}=\Sigma\left[(\mathrm{fo}-\mathrm{fh})^{2} / \mathrm{fh}\right]
$$

Keterangan :

Fo $\quad=$ Frekuensi udang jantan dan betina yang teramati.

fh $\quad=$ Frekuensi harapan, yaitu frekuensi udang jantan ditambah udang betina dibagi dua.

$\mathrm{X}^{2}=$ Sebuah nilai bagi peubah acak $\mathrm{x}^{2}$ yang sebaran penarikan contohnya menghampiri sebaran $\mathrm{x}^{2}$.

Hipotesis yang digunakan yaitu:

Ho : jika rasio udang jantan dan betina sama

$\mathrm{H} 1$ : jika rasio udang jantan dan betina berbeda

Pengambilan keputusan yaitu:

- $\mathrm{X}^{2}$ hitung $>\mathrm{X}^{2}$ tabel, tolak Ho terima H1

- $\mathrm{X}^{2}$ hitung $<\mathrm{X}^{2}$ tabel, terima Ho tolak H1

\section{Selektifitas Alat Tangkap}

Nilai selektifitas alat tangkap (SF) dapat dihitung dengan rumus (Sparre dan Venema, 1999)

Keterangan:

$$
\mathrm{SF}=\frac{\mathrm{Lc}_{50 \%}}{\text { mesh size }}
$$

$\mathrm{Lc}_{50 \%} \quad=$ Ukuran udang pertama kali tertangkap

Mesh size $\quad=$ Ukuran mata jaring $(\mathrm{mm})$

\section{HASIL DAN PEMBAHASAN}

Hasil

Komposisi Udang yang Tertangkap

Komposisi hasil tangkapan alat tangkap arad selama penelitian di perairan Utara Kendal tersaji dalam Gambar 1. 


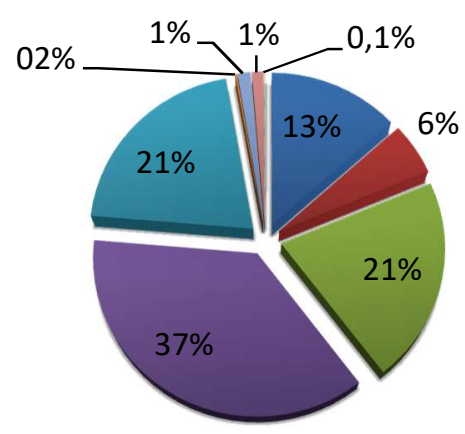
- Penaeus merguiensis
- Metapenaeus tenuipes
Penaeus indicus
metapenaeus conjunctus
- Metapenaeopsis barbata
- Penaeus monodon
Metapenaeus afinis
- Trachypenaeus Longipes
- Parapenaeopsis hardwickii

Gambar 1. Komposisi Udang Penaeid selama Penelitian yang Tertangkap Arad di Perairan Utara Kendal.

Berdasarkan Gambar 1 terlihat bahwa udang penaeid yang tertangkap terbesar adalah Metapenaeus conjunctus (37\%) dan yang terendah Trachypenaeus longipes sebesar (0,1\%), sedangkan udang P.merguiensis sebesar $13 \%$.

\section{Struktur Ukuran Udang P.merguiensis}

Sampel udang $P$. merguiensis yang didapat selama penelitian sebanyak 123 ekor. Struktur ukuran udang $P$. merguiensis selama penelitian tersaji pada Gambar 2.

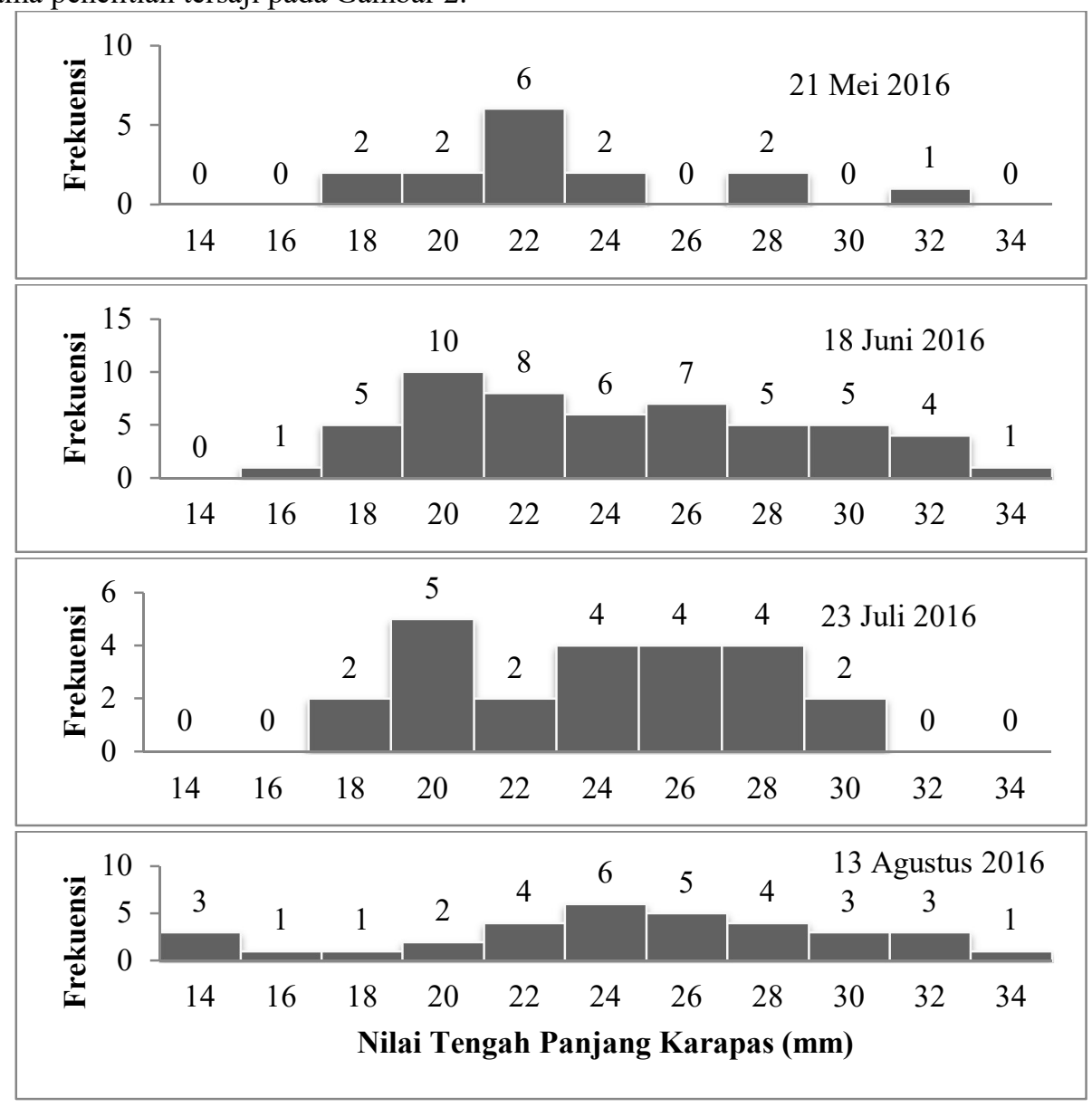

Gambar 2. Struktur Ukuran Udang P. merguiensis

Struktur ukuran udang $P$. merguiensis terlihat bahwa pada sampling pertama (Mei 2016), modus panjang karapas 22 mm, sampling kedua (Juni 2016) dan sampling ketiga modus panjang karapas tetap yaitu $20 \mathrm{~mm}$, sedangkan pada sampling keempat (Agustus 2016) modus panjang adalah $24 \mathrm{~mm}$.

\section{Hubungan Panjang dengan Bobot}

Analisa hubungan panjang dengan bobot digunakan untuk mengetahui sifat pertumbuhan udang $P$. merguiensis. Hubungan panjang dengan bobot udang $P$. merguiensis selama penelitian tersaji pada Tabel 1 . 
Tabel 1. Hasil Analisa Panjang dengan Bobot Udang P. merguiensis

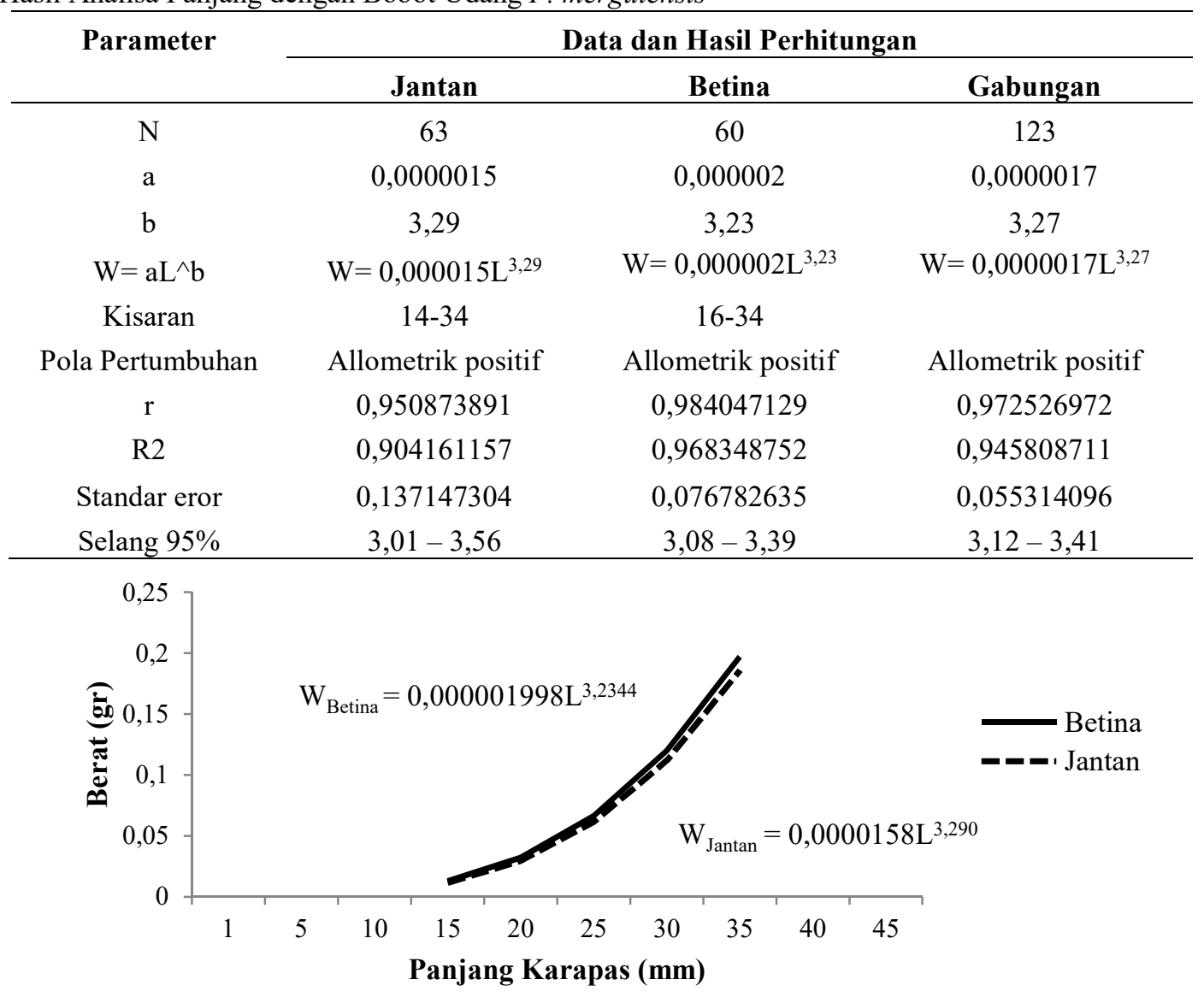

Gambar 3. Kurva Hubungan panjang dengan bobot udang P. merguiensis

Berdasarkan pengujian terhadap nilai b dengan t-test, udang $P$. merguiensis jantan dan betina mendapatkan hasil yang sama yaitu $\mathrm{t}$ hitung $>\mathrm{t}$ tabel, maka terima $\mathrm{H}_{1}$ dan tolak $\mathrm{H}_{0}$, yang berarti udang $P$. merguiensis memiliki sifat allometrik positif. Pertumbuhan allometrik positif yaitu pertambahan berat lebih cepat daripada pertambahan panjang.

\section{Faktor Kondisi}

Hasil perhitungan faktor kondisi tersaji pada Tabel 2.

Tabel 2. Nilai faktor Kondisi Udang P. merguiensis di Perairan Kendal

\begin{tabular}{cccc}
\hline Jenis Kelamin & Rata-rata L $(\mathbf{m m})$ & Rata-rata W $($ gr) & Faktor Kondisi \\
\hline Jantan & 121 & 11,943 & 1,0939 \\
Betina & 107,37 & 8,114 & 1,0963 \\
\hline
\end{tabular}

Berdasarkan data di atas didapatkan nilai faktor kondisi udang P. merguiensis jantan dan betina yaitu 1,0939 dan 1,0963. Hal ini menunjukan bahwa badan udang Jantan dan udang betina tingkat kemontokkannya tidak berbeda.

\section{Ukuran Pertama Kali Tertangkap}

Penentuan ukuran pertama kali tertangkap $\left(\mathrm{Lc}_{50 \%}\right)$ diperoleh dengan cara memplotkan panjang karapas udang berdasarkan kelompok panjang dengan jumlah udang yang tertangkap dalam persentase kumulatif. Ukuran pertama kali udang tertangkap tersaji pada Gambar 4 dan 5 .

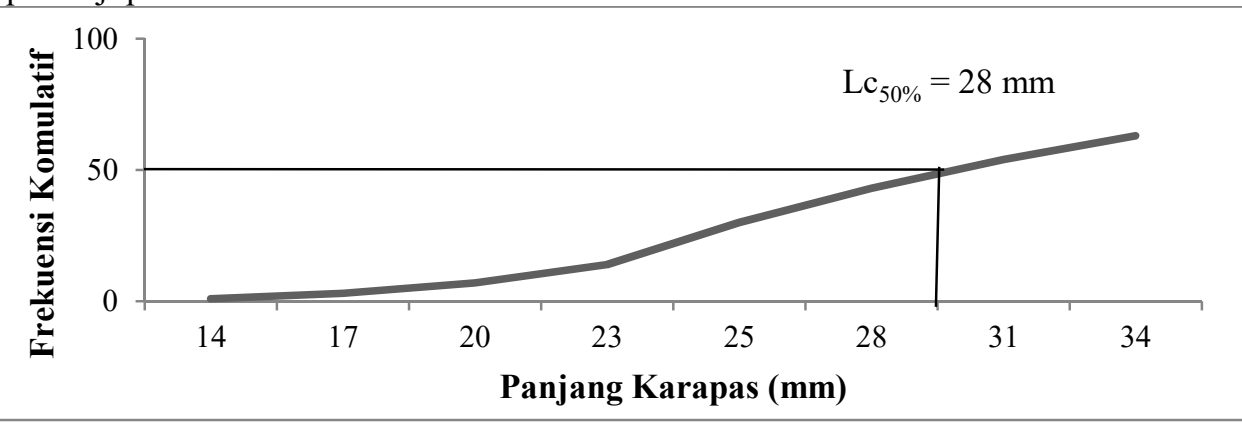

Gambar 4. Ukuran Pertama Kali Tertangkap udang P. merguiensis Jantan 


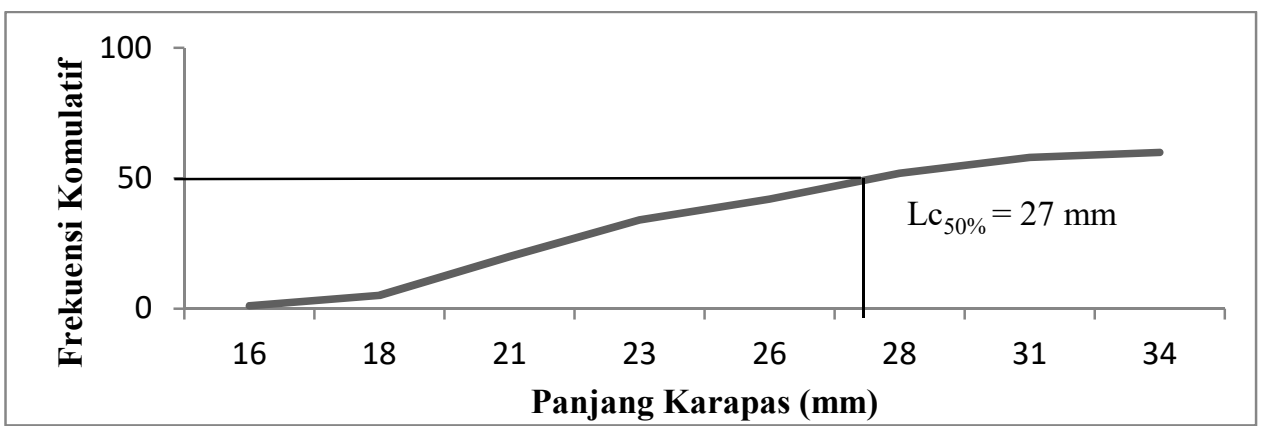

Gambar 5. Ukuran Pertama Kali Tertangkap udang P. merguiensis Betina

Ukuran pertama kali tertangkap udang P. merguiensis jantan dan betina berbeda yaitu $28 \mathrm{~mm}$ dan $27 \mathrm{~mm}$. Alat tangkap yang digunakan selama penelitian untuk menangkap udang $P$. merguiensis yaitu jaring arad. Arad merupakan alat tangkap yang tidak selektif. Ukuran mata jaring (mesh size) pada kantong arad yang digunakan untuk menangkap udang $P$. merguiensis sekitar 1 inci.

\section{Tingkat Kematangan Gonad}

Tingkat kematangan gonad merupakan tahap gonad mengalami perkembangan baik sebelum maupun setelah memijah. Hasil identifikasi Tingkat Kematangan Gonad (TKG) udang P. merguiensis jantan dan betina yang tertangkap selama penelitian bulan Mei sampai Agustus 2016 belum ada yang matang gonad.

\section{Nisbah Kelamin}

Perbandingan udang P. merguiensis jantan dengan betina disajikan pada Gambar 6.

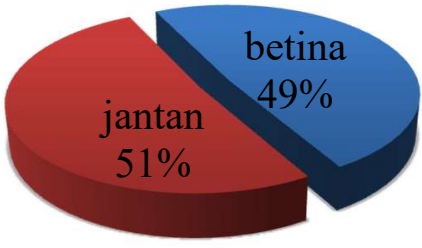

Gambar 6. Perbandingan Nisbah Kelamin Udang P. merguiensis Jantan dan Betina.

Jumlah udang yang didapatkan dalam penelitin ini terdiri dari 63 ekor udang jantan dan 60 ekor udang betina. Berdasarkan perhitungan nisbah kelamin didapatkan perbandingan udang jantan dan betina $1: 0,95$.

\section{Pembahasan}

\section{Komposisi Hasil Tangkapan}

Komposisi udang yang tertangkap jaring arad di perairan sebelah Utara Kendal didominasi oleh M. conjunctus yaitu sebesar 37\%. Sedangkan Udang P. merguiensis ditemukan sebesar 13\%. Menurut penelitian Khaerudin (2006) di Pesisir Utara Kota Cirebon, hasil tangkapan udang banyak didominasi oleh udang Dogol (Metapenaeus ensis) dan udang Krosok (Parapenaepsis sculptilis), sedangkan udang Jerbung (Penaeus merguiensis) 15\% dari tangkapan. Hal ini dikarenakan pengoperasian yang dilakukan pada saat penelitian adalah pada malam hari. Hal ini sama dengan penelitian Saputra et al. (2013) di perairan Cilacap Jawa Tengah, komposisi tangkapan udang selama penelitian Oktober 2012 Januari 2013 udang P. merguiensis yang tertangkap hanya $21 \%$ dari sejumlah sampel sebanyak $26,84 \mathrm{Kg}$.

\section{Struktur Ukuran Udang $P$. merguiensis}

Struktur ukuran panjang udang $P$. merguiensis yang tertangkap dengan arad di perairan sebelah Utara Kendal memiliki modus panjang karapas $22 \mathrm{~mm}$ pada sampling pertama (Mei 2016). Pada sampling kedua dan ketiga (Juni dan Juli 2016) modus panjang karapas terjadi perubahan menjadi $20 \mathrm{~mm}$, namun pada sampling keempat modus panjang karapas terjadi perubahan lagi menjadi $24 \mathrm{~mm}$. Modus ukuran panjang karapas tersebut lebih rendah dibandingkan dengan penelitian yang dilakukan oleh Tirtadanu dan Ernawati (2016) di perairan utara Jawa Tengah pada bulan April Agustus 2015 dengan modus panjang karapas P.merguensis $28 \mathrm{~mm}$. Modus ukuran panjang di daerah penelitian juga lebih rendah dibandingkan dengan penelitian Saputra et al. (2013) di perairan Cilacap pada bulan Oktober 2012 Januari 2013 dengan modus panjang karapas P.merguiensis sebesar 34-40 mm.

Menurut Subagyo dalam Khaerudin (2006), hal ini dikarenakan daerah penangkapan untuk jaring arad di Pesisir utara sebagian besar di daerah pantai, sehingga udang Jerbung yang didapat berukuran kecil atau masih muda. Untuk daerah penyebaran udang muda banyak terdapat dan terkonsentrasi di perairan pantai dan udang dewasa terkonsentrasi di perairan yang lebih dalam pada kedalaman 15-40 m. Hal ini sesuai dengan daur hidup udang $P$. merguiensis yang terbagi menjadi dua fase yaitu fase laut dan fase muara sungai. 
Ukuran pertama kali tertangkap ( $\mathrm{Lc}_{50}$ ) udang P. merguiensis jantan di perairan sebelah Utara Kendal pada ukuran karapas $28 \mathrm{~mm}$ dan udang betina pada ukuran karapas yaitu $27 \mathrm{~mm}$. Berdasarkan penelitian Mudhifasari (2009) di perairan sebelah Utara Bandengan Kendal mendapatkan ukuran pertama tertangkap pada panjang karapas $28,1 \mathrm{~mm}$. Berdasarkan penelitian Apriliyani (2012), di perairan Tanjung Rusa Belitung menemukan ukuran pertama tertangkap pada panjang karapas $51 \mathrm{~mm}$. Suman et al. (1994), dalam penelitiannya di perairan Demak menemukan ukuran pertama tertangkap pada panjang karapas $27,5 \mathrm{~mm}$. Berdasarkan uraian tersebut diketahui bahwa ukuran pertama tertangkap $\left(\mathrm{Lc}_{50 \%}\right.$ ), udang $P$. merguiensis di perairan Kendal mempunyai ukuran lebih kecil dibandingkan dengan perairan yang lainnya.

Nilai modus panjang karapas selama penelitian $(22-24 \mathrm{~mm})$ jika dibandingkan dengan nilai ukuran pertama kali tertangkap udang ( $27 \mathrm{~mm}$ dan $28 \mathrm{~mm}$ ), udang yang tertangkap diperairan Kendal memiliki ukuran yang terlalu kecil.

Udang hasil tangkapan selama penelitian yang paling besar 30-32 $\mathrm{mm}$ hanya ada beberapa ekor, sehingga kebanyakan memang belum ukurannya untuk memijah. Hasil penelitian Adisusilo dalam Suman et al. (1993), di perairan Cilacap diketahui $\mathrm{Lm}_{50 \%}$ udang P.merguiensis sebesar 39,59 mm. Penelitian Suman et al. (1994), di perairan Demak menunjukkan $\mathrm{Lm}_{50 \%}$ udang P.merguiensis pada panjang karapas 39,7 mm. Penelitian Kembaren (2013), di perairan pemangkat Kalimantan, ukuran udang Jerbung pertama kali matang gonad adalah pada panjang karapas 33,67 $\mathrm{mm}$.

Nilai $\operatorname{Lc}_{50 \%}(27 \mathrm{~mm}$ dan $28 \mathrm{~mm})<\operatorname{Lm}_{50 \%}(39,59)$ yang artinya ukuran pertama kali tertangkap udang $p$. merguiensis jantan dan betina memiliki ukuran yang lebih rendah daripada ukuran pertama kali matang gonad dari hasil penelitian Suman et al. (1993) di Perairan Cilacap. Hal ini menunjukkan bahwa ukuran udang yang tertangkap belum matang gonad, ukuran terlalu kecil dan belum mempunyai kesempatan udang untuk memijah.

\section{Nisbah Kelamin}

Nisbah kelamin antara udang $P$. merguiensis jantan dan betina yaitu sebesar $1: 0,95$. Perbandingan udangjantan dan betina masih dikatakan normal, akan tetapi lebih baik udang betina lebih banyak dari udang jantan. Menurut Saputra et al. (2009), apabila jantan dan betina seimbang atau betina lebih banyak dapat dikatakan bahwa populasi tersebut masih ideal untuk mempertahankan kelestariannya. Hasil seimbang ini berbeda dengan penelitin Saputra et al. (2013) di perairan Cilacap, nisbah kelamin didapat perbandingan udang jantan dan betina 1:1,61. Berbeda juga dengan penelitian Tirtadanu dan Ernawati (2016) di perairan utara Jawa Tengah pada bulan April, Mei dan Juni berada dalam kondisi seimbang, sedangkan bulan Juli dan Agustus perbandingan jantan dan betina 1:4,41, pada bulan Juli 1:2,39, pada bulan Agustus. Berdasarkan uraian tersebut perbandingan udang jantan dan betina di perairan sebelah Utara Kendal berbeda dengan perairan yang lainnya kecuali pada perairan utara Jawa Tengah pada bulan April, mei, dan Juni.

\section{Sifat Pertumbuhan Udang $P$. merguiensis}

Hubungan panjang dan bobot udang merupakan salah satu parameter yang digunakan untuk menganalisis pola pertumbuhan suatu kelompok udang, berguna dalam kegiatan pengelolaan perikanan. Berdasarkan hasil perhitungan hubungan panjang dan berat Udang $P$. merguiensis jantan dan betina diperoleh nilai b 3,290 dan 3,234. Nilai $\mathrm{b}>3$ dapat disebutkan bahwa pola pertumbuhan udang jantan dan betina alometrik positif, yaitu pertambahan berat lebih cepat daripada pertambahan panjang. Pola pertumbuhan udang jantan dan betina mempunyai pola pertumbuhan yang relatif sama. Sifat pertumbuhan tersebut berbeda dengan penelitian Tirtadanu dan Ernawati (2016) di perairan utara Jawa Tengah yaitu allometrik negatif yaitu 2,3169 jantan dan 2,327 betina. Berbeda juga dengan penelitian Saputra et al. (2013) di perairan pantai Cilacap, sifat pertumbuhan udang jantan allometrik negatif yaitu 2,026 sedangkan udang betina memiliki sifat isometrik yaitu 3,105. Perbedaan pertambahan berat udang jantan dan betina berkaitan dengan umur udang. Selain itu udang betina mempunyai kemampuan yang lebih baik untuk beradaptasi dengan lingkungan dan mengasimilasi makanan menjadi daging dibandingkan udang jantan. Pada udang dewasa pertambahan panjang melambat dan pertambahan berat semakin cepat.

\section{Faktor Kondisi}

Udang P. merguiensis yang terdapat di perairan Kendal memiliki nilai faktor kondisi sebesar 1,0939 untuk jantan dan 1,0963 untuk betina. Hal ini menunjukan bahwa udang P. merguiensis jantan dan betina memiliki tingkat kemontokkan yang tidak berbeda. Berdasarkan penelitian Mudhifasari (2009) di perairan Kendal menunjukkan faktor kondisi jantan dan betina sebesar 1,547 dan 1,743. Berdasarkan penelitian Setiyoso (2006) di perairan Kebumen memiliki faktor kondisi jantan 1,153 dan betina 1,187. Berdasarkan penelitian Saputra et al. 2013 di perairan Cilacap memiliki nilai faktor kondisi udang betina 2,051 dan jantan 1,152. Berdasarkan uraian tersebut udang P. merguiensis di perairan Kendal memiliki kemontokan yang lebih kecil dibandingkan perairan Cilacap. Menurut Saputra (2009), nilai $\mathrm{Kn}$ tidak berarti apa-apa jika dilihat sendiri sebagai angka tunggal. Jika dibandingkan dengan individu lainnya atau kelompok atau ukuran dengan ukuran lain yang berasal dari berbagai lokai yang berbeda.

\section{Konsep Pengelolaan Udang $P$. merguiensis di Perairan Kendal}

Berdasarkan keadaan karakteristik biologis udang $P$. merguiensis yang tertangkap selama penelitian maka sangat diperlukan usaha-usaha yang dapat memberikan kesempatan pada udang-udang muda untuk tumbuh dan memijah, sehingga populasi udang $P$. merguiensis yang ada tetap lestari. Usaha-usaha tersebut antara lain meningkatkan ukuran yang tertangkap, mengatur besarnya mesh size jaring yang digunakan agar udang yang tertangkap adalah udang 
berukuran layak tangkap, alat tangkap arad diganti dengan alat tangkap yang selektif dan pengaturan daerah pengoperasian.

Arad merupakan alat tangkap yang tidak selektif, dengan mesh size yang sangat kecil sehingga tingkat selektifitas alat tangkap juga rendah. Akibatnya banyak udang yang belum layak tangkap oleh arad. Untuk mengurangi hal tersebut salah satunya dengan mengganti alat tangkap arad menjadi trammel net, dengan ukuran mesh size yang tepat. Selain ukuran mata jaring dan waktu penangkapan, pengaturan daerah pengoperasian alat tangkap juga perlu dilakukan. Pengaturan daerah pengoperasian dilakukan jauh dari pantai agar udang yang tertangkap adalah udang berukuran layak tangkap.

Ukuran mesh size pada kantong alat tangkap arad yang dijadikan sampel dan digunakan untuk menangkap udang di perairan Utara Kendal adalah 1 inci $(25,4 \mathrm{~mm})$ dengan faktor selektifitas melalui persamaan $\mathrm{Lc}_{50 \%} /$ mesh size yaitu $0,984 \mathrm{~mm}$. Pemanfaatan udang P.merguiensis yang tidak optimum, cenderung terjadi pemborosan sumberdaya serta mengancam kelestariannya. Sehingga diperlukan pengaturan terhadap penangkapan di perairan tersebut. Salah satunya dengan menggunakan alat tangkap yang selektif dengan ukuran mesh size yang besar. supaya udang P.merguiensis yang tertangkap di perairan Utara Kendal merupakan udang yang layak tangkap, Penggunaan mesh size yang lebih besar diharapkan udang P.merguiensis yang masih berukuran kecil dapat lolos dan tumbuh hingga siap pada ukuran layak tangkap, sehingga kelestarian udang P.merguiensis di perairan Utara Kendal dapat terjaga.

\section{Kesimpulan \\ Kesimpulan}

Kesimpulan yang dapat disampaikan adalah sebagai berikut:

1. Beberapa aspek biologi udang P. merguiensis yaitu:

a) Struktur ukuran udang $P$. merguiensis selama penelitian di perairan sebelah utara Kendal didominasi modus panjang karapas $20 \mathrm{~mm}$ pada bulan juni dan juli 2016, sedangkan pada bulan mei dan agustus modus panjang karapas $22 \mathrm{~mm}$ dan $24 \mathrm{~mm}$.

b) Nisbah kelamin udang $P$. merguiensis jantan dan betina yaitu sebesar $1: 0,95$.

c) Faktor kondisi udang P. merguiensis jantan dan betina sebesar 1,0939 dan 1,0963. Hal ini menunjukan bahwa badan udang jantan dan udang betina tingkat kemontokkannya tidak berbeda. Sifat pertumbuhan udang $P$. merguiensis yaitu allometrik positif.

d) Selama penelitian tidak didapatkan udang yang matang gonad.

e) $\mathrm{Lc}_{50 \%}$ udang $P$. merguiensis jantan di Perairan sebelah Utara Kendal pada ukuran karapas $28 \mathrm{~mm}$ dan udang betina $27 \mathrm{~mm}$. Hal ini menandakan bahwa udang yang terangkap didominasi udang kecil yang belum layak tangkap.

2. Konsep pengelolaan udang $P$. merguiensis di perairan Kendal yaitu dengan memberikan kesempatan terhadap udang muda untuk tumbuh dan memijah, dengan penggantian Alat tangkap jaring arad dan yang sejenis dengan alat tangkap yang selektif yaitu Trammel net dan daerah pengoperasian dilakukan jauh dari pantai.

\section{Ucapan Terimakasih}

Penulis menyampaikan ucapan terimakasih kepada Ir. Siti Rudiyanti, M.Si yang telah membantu dan memberikan bimbingan dalam penelitian serta semua pihak yang telah membantu terlaksananya penelitian sampai dengan selesai

\section{Daftar Pustaka}

Effendi, M.I., 2002. Biologi Perikanan. Yayasan Pustaka Nusantara, Yogyakarta.

Apriliyani, N. F. 2012. Studi Tentang Udang Penaeid yang Tertangkap dengan Jaring Trammel di Perairan Desa Tanjung Rusa Kabupaten Belitung. Fakultas Perikanan dan Ilmu Kelautan, Universitas Diponegoro, Semarang, $89 \mathrm{hlm}$.

Kembaren, D. 2013. Aspek Biologi Udang Jerbung (Penaeus Merguiensis De Man) Di Perairan Pemangkat, Kalimantan Barat. Balai Penelitian Perikanan Laut. Vol. 16 No.3, Desember 2013: 371-376

Khaerudin, A., 2006. Proporsi Hasil Tangkap Sampingan Jaring Arad (Mini Trawl) yang Berbasis di Pesisir Utara, Kota Cirebon. Skripsi. Institut Pertanian Bogor. Bogor

King, M. 1995. Fisheries Biology, Ascessment and Management. Fishing News Books a Division of Blackwell Science ltd, London. 151-156 pp.

Mudhifasari, F.D. 2009. Beberapa Aspek Biologi dan Potensi Pemanfaatan Udang Jerbung (Penaeus merguiensis de Man) di Perairan Bandengan Kabupaten Kendal. Fakultas Perikanan dan Ilmu Kelautan, Universitas Diponegoro, Semarang, $87 \mathrm{hlm}$.

Mustafa, H. 2000. Teknik Sampling. http://home.unpar.ac.id/hasan/sampling.doc. (11 November 2015)

Saputra, S.W., 2009. Dinamika Populasiikan. Universitas Diponegoro. 199 Hlm. 
Saputra, S. W., P. Soedarsono dan G.A. Sulistyawati. 2009. Beberapa Aspek Biologi Ikan Kuniran (Upeneus spp.) di Perairan Demak. J. Saintek Perikanan. 5(1):1-6.

Saputra, S.W., Djuwito, dan A. Rutiyaningsih. 2013. Beberapa Aspek Biologi Udang Jerbung (Penaeus merguiensis) di Perairan Pantai Cilacap Jawa Tengah. Journal Maquares. 2 hal. 47-55

Setiyoso, M.O. 2006. Potensi dan Tingkat Pemanfaatan Udang Jerbung (Penaeus merguiensis de Man) yang di Daratkan di TPI Kabupaten Kebumen. Fakultas Perikanan dan Ilmu Kelautan, Universitas Diponegoro, Semarang. $91 \mathrm{hlm}$.

Sparre, Per dan Seibren C.Venema. 1999. Introduksi Kajian Stok Ikan Tropis. Pusat Penelitian dan Pengembangan Perikanan (Berdasarkan kerjasama dengan FAO). Jakarta.

Subagyo, Waluyo. 2005. Status Penangkapan Udang Jerbung (Penaeus merguiensis de man) di Perairan Cilacap dan Sekitarnya Serta Usulan Pengelolaannya. Disertasi. Institut Pertanian Bogor. Bogor.

Suman, A., M. Rijal dan Manadiyanto. 1993. Jenis Hubungan Panjang Berat, Ukuran Matang Gonad dan Potensi Perikanan Udang di Perairan Kutai Kalimantan Timur. J. Perikanan Laut, 81:76-83.

Suman, A., M. Rijal dan Yulianti. 1994. Biologi dan Dinamika Populasi Udang Jerbung (Penaeus merguiensis de Man) di Perairan Demak, Jawa Tengah. J. Perikanan Laut, 87: 10-21.

Suparjo, M.N. 2005. Potensi Udang Dogol (Metapenaeus ensis) di Kabupaten Kebumen Jawa Tengah. J. Perikanan, 84-92.

Tirtadanu dan Ernawati, T. 2016. Kajian Biologi Udang Jerbung (Penaeus merguiensis De Man, 1888) di Perairan Utara Jawa Tengah. BAWAL. 8 (2): 109-116 